\title{
Assessment of the impact of compliance risks of residents of priority development territories on the sustainable state of the economy of the Russian Far East
}

\author{
Vilena Yakimova* \\ Amur State University, Ignatievskoe Str., 21, 675000 Blagoveshchensk, Russia
}

\begin{abstract}
The sustainable and balanced development of the economy of the Russian Far East is determined by many factors, including the financial condition of business structures and the ability to resist threats from the external environment. Compliance risks are considered as threats to a sustainable state, the consequences of which in relation to residents of priority development territories can be expressed in the loss of solvency, reduction of their own sources of financing and bankruptcy of economic entities. The article proposes a methodology for assessing compliance risks, consisting of indicators and established risks threshold values. On the basis of the developed methodology, an assessment was made, areas of risk and possible consequences that affect the stable state of priority development territories were identified. The indicators and assessment results can be used to monitor and improve the mechanisms for managing the economy of the Far East of Russia.
\end{abstract}

\section{Introduction}

The stable economic state of the Russian Far East is one of the priority directions of the state's strategic policy. The factors that ensure the sustainable state of the territories are the economic, environmental and social conditions for the reproduction of production, human and natural capital. The sustainable development is a process of change in which the exploitation of natural resources, the direction of investment, the orientation of scientific and technological progress, personal development and institutional changes are coordinated with each other, strengthening the future potential to meet the human needs [1]. Only the sustainable organizations can guarantee the economic security of the Far East.

In order to improve the quality of life of the population and create a stable environment for the implementation of investment and infrastructure facilities, territories with a special economic status have been created since 2015. The activities of the residents of the priority development territories, which is stimulated by the inflow of budgetary and private investments in conditions of preferential tax regimes, are aimed at increasing the volume of manufacturing, attracting qualified labor to the regions, and creating a stable export potential. At the same time, the state expects to receive an economic effect, expressed in the

${ }^{*}$ Corresponding author: vilena_yakimova@mail.ru 
growth of GDP and investments, and the creation of new jobs. Key indicators of the sustainability of the socio-economic development of the Russian Far East are defined in Table 1.

Table 1. Indicators for assessing the sustainable socio-economic development of the Russian Far East

\begin{tabular}{|c|c|c|c|c|c|c|c|c|c|c|}
\hline \multirow{3}{*}{ Indicators } & \multicolumn{10}{|c|}{$\begin{array}{l}\text { The rate of change of the indicator of the current year to the previous } \\
\text { one, } \%\end{array}$} \\
\hline & \multicolumn{2}{|c|}{$\begin{array}{c}2014 \text { to } \\
2013\end{array}$} & \multicolumn{2}{|c|}{$\begin{array}{c}2015 \text { to } \\
2014\end{array}$} & \multicolumn{2}{|c|}{$\begin{array}{l}2016 \text { to } \\
2015\end{array}$} & \multicolumn{2}{|c|}{2017 to 2016} & \multicolumn{2}{|c|}{$\begin{array}{c}2018 \text { to } \\
2017\end{array}$} \\
\hline & 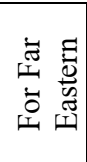 & 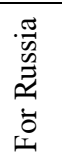 & 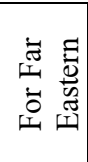 & 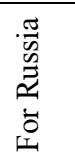 & 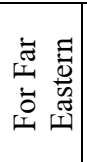 & 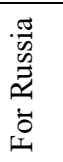 & 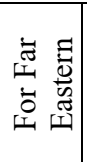 & 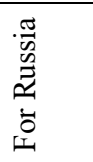 & 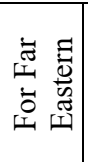 & 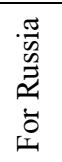 \\
\hline $\begin{array}{l}\text { Investment in } \\
\text { fixed assets }\end{array}$ & 97 & 103 & 111 & 100 & 110 & 106 & 115 & 109 & 108 & 110 \\
\hline GRP (per capita) & 114 & 107 & 112 & 111 & 104 & 105 & 105 & 108 & 101 & 113 \\
\hline Export volume & 107 & 95 & 75 & 69 & 118 & 83 & 108 & 125 & 97 & 126 \\
\hline $\begin{array}{l}\text { Depreciation of } \\
\text { fixed assets at the } \\
\text { end of the year }\end{array}$ & 114 & 103 & 110 & 102 & 106 & 103 & 108 & 101 & 104 & 100 \\
\hline $\begin{array}{ll}\text { Share } & \text { of } \\
\text { unprofitable } & \\
\text { organizations } & \end{array}$ & 111 & 106 & 98.2 & 99 & 90 & 90 & 106 & 108 & 106 & $\begin{array}{c}103 \\
7\end{array}$ \\
\hline $\begin{array}{l}\text { Volume of tax } \\
\text { revenues to the } \\
\text { budget }\end{array}$ & 125 & 108 & 126 & 107 & 97 & 109 & 92.5 & 108 & 125 & 115 \\
\hline Population & 100 & 102 & 100 & 100 & 100 & 100 & 99.7 & 100.1 & 99.6 & 99.9 \\
\hline $\begin{array}{l}\text { Demographic } \\
\text { load factor }\end{array}$ & 104 & 104 & 104 & 104 & 103 & 103 & 103 & 1038 & 102 & 102 \\
\hline $\begin{array}{l}\text { Migration gain } \\
\text { (in absolute } \\
\text { terms) }\end{array}$ & -39 & 19 & -40 & 17 & -33 & 18 & -35 & 14 & -40 & 9 \\
\hline $\begin{array}{l}\text { Average } \\
\text { unemployment } \\
\text { rate per year }\end{array}$ & 98 & 95 & 98 & 108 & 92 & 98 & 97 & 95 & 112 & 92 \\
\hline
\end{tabular}

The indicators in Table 1 indicate that in the course of the implementation of the state tasks of economic development, entrepreneurship is faced with the threats and challenges due to both the peculiarities of the Far Eastern regions and new economic realities. A positive trend is the growth of the investment activity in all regions of the Russian Far East. In the Amur Region (development of the infrastructure of the Vostochny cosmodrome and construction of a gas processing plant, the Power of Siberia gas pipeline) and in Yakutia (Ogodzhinskoye coal deposit of Mechel Group of Companies). The disproportions in the economic development of the macroregion are manifested in the growth of investments with a decrease in the population and a slowdown in the growth of GRP per capita. At the same time, there are the threats of loss of stability, such as the outflow of the population, the growth of the dependency ratio, property differentiation of the population, the growth of unemployment, unprofitable organizations and a slowdown in tax revenues to the budget. The reasons for migration, as a rule, are the high cost of living, dissatisfaction with wages and place of work, low level of accessibility and quality of social services, high transport tariffs, remoteness from the Central part of Russia [2]. A significant threat is the increase in the wear and tear of the equipment of the enterprises, which can reduce the competitiveness of enterprises and cause an inability to implement the investment projects. A large base of 
production equipment in the Far East remained from the Soviet era and has not been modernized for a long time due to insufficient funding.

Threats from the external and internal environment of the residents that are part of the priority development territories have a negative impact on the financial and socio-economic system of the Russian Far East. Every enterprise is faced with many factors that, if negatively affected, threaten to cause serious damage to the macroeconomic system. In modern conditions, compliance risks become important in the structure of economic risks, which are understood as "the risks of applying legal and regulatory sanctions of regulatory bodies, material and financial losses or damage to reputation as a result of non-compliance with laws, instructions, rules, standards or codes of conduct" [ 3], [4], [5]. P. Benedek considers the risks associated with fraud, corruption, violation in the field of production safety, health, non-compliance with the environmental requirements, intellectual property, non-compliance with antimonopoly legislation, violation of the employment rules, social responsibility and human rights [6]. V. Kh. Valiev singled out as compliance risks the following - bribery, underdevelopment of the organization's anti-corruption policy, the risks of corruption in contacts with government bodies, licensing, public procurement, organizing the tenders [7]. In our opinion, compliance risks should be grouped as follows: operational, reputational and regulatory ones, with their division into risks of intentional and unintentional violation of the law. This classification is of prime importance for identifying the causes and predicting the consequences of the risks.

Compliance risks destabilize the conditions for the development of the residents at the micro level, hinder the implementation of the socio-economic interests of the investors, society and the state [8]. A negative manifestation of compliance risks is the influence of the company's unfair behavior on transactions with various persons interested in cooperation [9]. Fraud and "destructive entrepreneurship" is destructive for the business environment and the regional economy, as it generates chain bankruptcies [10]. The danger of the manifestation of compliance risks is expressed in a possible reduction in production and investment potential, irrational use of financial resources, restraint of the growth rate of socio-economic indicators. Due to their uncertainty in the spheres of influence and the unpredictability of financial damage, compliance risks require prompt detection, forecasting and response to a risk situation.

\section{Materials and Methods}

To assess the likelihood of the emergence of the compliance risks, a system of indicators has been developed that takes into account the factors of their manifestation, as well as the features of economic development territories as economic systems. The indicative method allows you to signal the early manifestation of negative events and determine the speed of spread of the risks. The proposed system of indicators is based on an integrated approach that provides a versatile assessment, as well as the relationship of residents' indicators with macroeconomic, regional and sectoral indicators. The indicators include those characterizing highly sensitive changes in the internal and external compliance environment.

As a source of information for assessing the internal factors, the data of the accounting statements of residents were used, for assessing external factors, data from open data Internet sites (FTS, bailiff services, etc.) and official statistical information.

For a comparative and comprehensive assessment, to determine the level of compliance risk, it is proposed to translate the calculated analytical indicators into a score. The most acceptable range of the risk level in points is determined $\mathrm{r} \in[0 ; 5] \%$ split into three levels: low $\mathrm{r} \in[0 ; 1.66] \%$, medium $\mathrm{r} \in[1.67 ; 3.33] \%$, high $\mathrm{r} \in[3.34 ; 5] \%$. To calculate the level of risk included in the appropriate interval in points, it is proposed to use formula 1 : 


$$
r=r_{\min }+\frac{I_{\text {max }}-I_{i}}{I_{\text {max }}-I_{\text {min }}}\left(r_{\text {max }}-r_{\text {min }}\right),
$$

where $\mathrm{I}$ is a risk indicator, $\mathrm{r}$ is a risk level in points.

The boundaries of the indicators corresponding to the level of risk are presented in Table 2. The minimum and maximum limits are selected based on the worst and best values. In order to take into account the unidirectionality of the action of factors for some indicators, their inverse is introduced.

Table 2. Indicators for assessing the level of compliance risks for the territories of priority social and economic development of the Far Eastern Federal District and the boundaries of their value

\begin{tabular}{|c|c|c|c|c|}
\hline \multirow{3}{*}{$\begin{array}{l}\text { Designat } \\
\text { ion }\end{array}$} & \multirow{2}{*}{\multicolumn{2}{|c|}{ Risk assessment indicator }} & \multicolumn{2}{|c|}{ Risk level } \\
\hline & & & Mediu & High \\
\hline & Risk level in points & {$[0 ; 1.67)$} & $\begin{array}{l}1.67 \\
3.33)\end{array}$ & [3.33; \\
\hline R 1 & \multicolumn{4}{|c|}{ Risks arising from erroneous (accidental) actions and events of force majeure } \\
\hline R 1.1. & \multicolumn{4}{|c|}{$\begin{array}{c}\text { Reputational risks (loss of internal reputation, business reputation in commodity, stock and } \\
\text { other markets) }\end{array}$} \\
\hline R 1.1.1 & $\begin{array}{l}\text { Share of residents who have not had a change of } \\
\text { personnel management over the past } 3 \text { years, } \%\end{array}$ & $>75$ & {$[50 ; 75)$} & {$[0 ; 50)$} \\
\hline R 1.1.2 & Sales growth rate per 1 resident, $\%$ & $>120$ & {$[100 ; 120)$} & {$[0 ; 100)$} \\
\hline R 1.1.3 & Share of financially stable residents, $\%$ & $>75$ & {$[50 ; 75)$} & {$[0 ; 50)$} \\
\hline R 1.1 .4 & $\begin{array}{l}\text { Share of residents with a low level of bankruptcy } \\
\text { probability, } \%\end{array}$ & $>75$ & {$[50 ; 75)$} & {$[0 ; 50)$} \\
\hline R 1.1 .5 & Share of solvent residents, $\%$ & $>75$ & {$[50 ; 75)$} & {$[0 ; 50)$} \\
\hline R 1.1 .6 & Share of residents without dependence on debtors, ${ }^{0}$ & $>75$ & {$[50 ; 75)$} & {$[0 ; 50)$} \\
\hline R 1.1.7 & Share of residents who have no debt from creditors & $>75$ & {$[50 ; 75)$} & {$[0 ; 50)$} \\
\hline R 1.1 .8 & $\begin{array}{l}\text { Share of residents who were not included in the } \\
\text { register of mass founders in the total number of the } \\
\text { territories of priority social and economic developn } \\
\text { residents, } \%\end{array}$ & $>75$ & {$[50 ; 75)$} & {$[0 ; 50)$} \\
\hline R 1.2 . & \multicolumn{4}{|c|}{ Regulatory (legal) risks } \\
\hline R 1.2 .1 & \multicolumn{4}{|c|}{ Regulatory risks: violations of general legislation (labor, tax, accounting, banking) } \\
\hline R 1.2.1.1 & $\begin{array}{l}\text { The amount of tax debt and enforcement } \\
\text { proceedings to the amount of residents' own } \\
\text { capital }\end{array}$ & 0 & $\begin{array}{l}{[0.0001} \\
0.02)\end{array}$ & $>0.02$ \\
\hline R 1.2 .2 & $\begin{array}{l}\text { Share of residents who do not have tax debts and } \\
\text { enforcement claims, } \%\end{array}$ & $>90$ & {$[75 ; 90)$} & {$[0 ; 75)$} \\
\hline R 1.2 .2 & \multicolumn{4}{|c|}{$\begin{array}{c}\text { Regulatory risks: risks of violation of special legislation (antimonopoly, trade, currency, } \\
\text { customs) }\end{array}$} \\
\hline R 1.2.2.1 & $\begin{array}{l}\text { The volatility of federal and regional policy in } \\
\text { terms of the territories of priority social and } \\
\text { economic development }\end{array}$ & 1 & - & 0 \\
\hline R 1.2.2.2 & $\begin{array}{l}1 \text { - The rate of retirement of residents due to non- } \\
\text { compliance with the requirements for resident } \\
\text { status, bankruptcy of organizations and other } \\
\text { reasons }\end{array}$ & {$[1 ; 0.9)$} & {$[0.7 ; 0.9)$} & {$[0 ; 0.7]$} \\
\hline $\mathrm{R} 1.2 .3$ & \multicolumn{4}{|c|}{ Risks of inspections, violation of requirements of supervisory authorities } \\
\hline R 1.2.3.1 & $\begin{array}{l}\text { Share of residents who do not have violations of } \\
\text { the law, } \%\end{array}$ & $>90$ & {$[75 ; 90)$} & {$[0 ; 75)$} \\
\hline R 2 & \multicolumn{4}{|c|}{ Risks arising from willful fraud } \\
\hline R 2.1 & $1 /$ level of economic crime in the region & $>1$ & {$[0.05 ; 1)$} & $<0,05$ \\
\hline R 2.2 & $100 \%$ - corruption level in the region & $>85$ & {$[50 ; 85)$} & {$[0 ; 50)$} \\
\hline
\end{tabular}

A high-level risk assessment is a threshold value for system resilience. The system of developed indicators can be used to predict and monitor the state of socio-economic indicators both in the priority development territories and in the regions where they operate. 
Based on the risk assessment, it is possible to predict the economic damage due to violations of legislation and economic crimes by the residents.

\section{Results and Discussion}

There are 20 priority development territories in the Russian Far East, in which there are over 400 residents. Due to investment and entrepreneurial interest, the largest number of enterprises and individual entrepreneurs received the status of residents in the Primorsky and Kamchatka Territories, in the Chukotka Autonomous District. A feature of the structure of the priority development territories is the predominance of small businesses, as well as enterprises implementing projects at the investment stage. About $32 \%$ of the total are the residents who were created less than a year before obtaining the resident status. Small businesses and organizations in the early stages of their life cycle are more exposed to risks and less capable of implementing recovery measures.

On the basis of the proposed indicators of risk assessment, indicators for the territories of priority social and economic development of the Far Eastern Federal District were calculated. The results are shown in Table 3. The summary comprehensive assessment is shown in Fig. 1.

Table 3. Assessment of compliance risk indicators for residents of the priority development territories of the Russian Far East

\begin{tabular}{|c|c|c|c|c|c|c|c|c|c|c|c|c|c|c|c|c|c|}
\hline Risk & 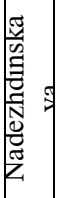 & 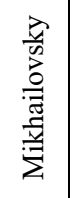 & 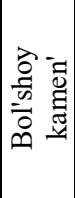 & 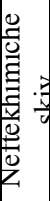 & 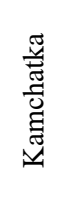 & 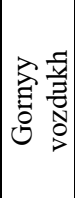 & 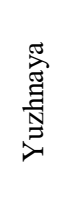 & 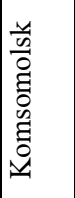 & $\begin{array}{l}\frac{y}{n} \\
\frac{y}{0} \\
\frac{\pi}{0} \\
\frac{0}{3} \\
\frac{3}{z}\end{array}$ & 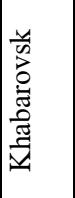 & 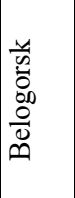 & 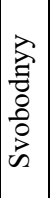 & 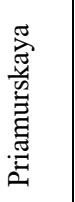 & 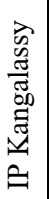 & 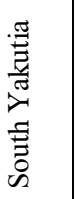 & 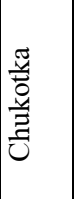 & 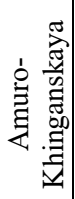 \\
\hline 1.1 .1 & \begin{tabular}{|l|}
91 \\
\end{tabular} & 88 & 75 & 0 & 87 & 72 & 63 & 58 & \begin{tabular}{|l|}
100 \\
\end{tabular} & 100 & 56 & 71 & 67 & 100 & 93 & 100 & 67 \\
\hline 1.1 .2 & 98 & 83 & 221 & 0 & 77 & 24 & 45 & 120 & 72 & 109 & 78 & 902 & 224 & 113 & 95 & 228 & 188 \\
\hline 1.1 .3 & 14 & 17 & 14 & 0 & 38 & 19 & 57 & 9.5 & 80 & 15 & 20 & 33 & 38 & 33 & 36 & 38 & 33 \\
\hline 1.1 .4 & \begin{tabular}{|l|}
43 \\
\end{tabular} & 69 & 27 & 0 & 69 & 40 & 71 & 17 & 80 & 62 & 89 & 71 & 56 & 67 & 30 & 78 & 33 \\
\hline 1.1 .5 & 54 & 50 & 14 & 0 & 40 & 56 & 71 & 14 & 100 & 41 & 0 & 100 & 25 & 44 & 18 & 29 & \\
\hline 1.1 .6 & \begin{tabular}{l|l|}
64 & \\
\end{tabular} & 77 & 45 & 100 & 70 & 60 & 63 & 83 & 71 & 68 & 89 & 71 & 22 & \begin{tabular}{|l|}
68 \\
\end{tabular} & 53 & 88 & 33 \\
\hline 1.1 .7 & 95 & 82 & 70 & 100 & 91 & 88 & 75 & 71 & 71 & 89 & 100 & 86 & 67 & \begin{tabular}{|l|}
68 \\
\end{tabular} & 87 & 96 & 100 \\
\hline 1.1 .8 & 95 & 82 & 100 & 100 & 94 & 68 & 75 & 83 & 86 & 95 & 100 & 100 & 89 & 100 & 93 & 98 & 100 \\
\hline & \begin{tabular}{|l|}
0.0 \\
009
\end{tabular} & 0.04 & 0.05 & \begin{tabular}{|c|}
0.0 \\
5 \\
\end{tabular} & 0.04 & 0.002 & 0.01 & 1 & 0.03 & 0.04 & 0 & 0 & 0.13 & \begin{tabular}{|c|}
0.0 \\
2 \\
\end{tabular} & 0.02 & 0.06 & 0.36 \\
\hline R 1.2.2 & 88 & 64 & 17 & 0 & 33 & 65 & 43 & 43 & 40 & 56 & 88 & 33 & 60 & 18 & 60 & 35 & 67 \\
\hline 2.2 .1 & 1 & 1 & 1 & 1 & 1 & 1 & 1 & 1 & 1 & 1 & 1 & 1 & 1 & 1 & 1 & 1 & 1 \\
\hline 2.2 .2 & 0.8 & 0.9 & 0.8 & 1 & 1 & 1 & 1 & 0.7 & 1 & 0.8 & 0.9 & 1 & 0.9 & \begin{tabular}{|c|}
0.8 \\
3 \\
\end{tabular} & 1 & 1 & 0. \\
\hline 2.3 .1 & 100 & 98 & 91 & 100 & 88 & 98 & 93 & 88 & 99 & 00 & 97 & 94 & 88 & 100 & 89 & 98 & 96 \\
\hline R 2.1 & \begin{tabular}{|c|}
0.0 \\
4
\end{tabular} & 0.04 & 0.04 & \begin{tabular}{|c|}
0.0 \\
4 \\
\end{tabular} & 0.12 & 0.11 & 0.11 & 0.05 & 0.05 & 0.05 & 0.08 & \begin{tabular}{|c|}
0.0 \\
8 \\
\end{tabular} & 0.08 & \begin{tabular}{|c|}
0.0 \\
6 \\
\end{tabular} & 0.06 & 1.01 & 0.36 \\
\hline 2.2 & \begin{tabular}{|l|}
35 \\
\end{tabular} & 35 & 35 & 35 & 85 & 79 & 79 & 55 & 55 & 55 & 77 & 77 & 77 & 85 & 85 & 100 & 96 \\
\hline
\end{tabular}




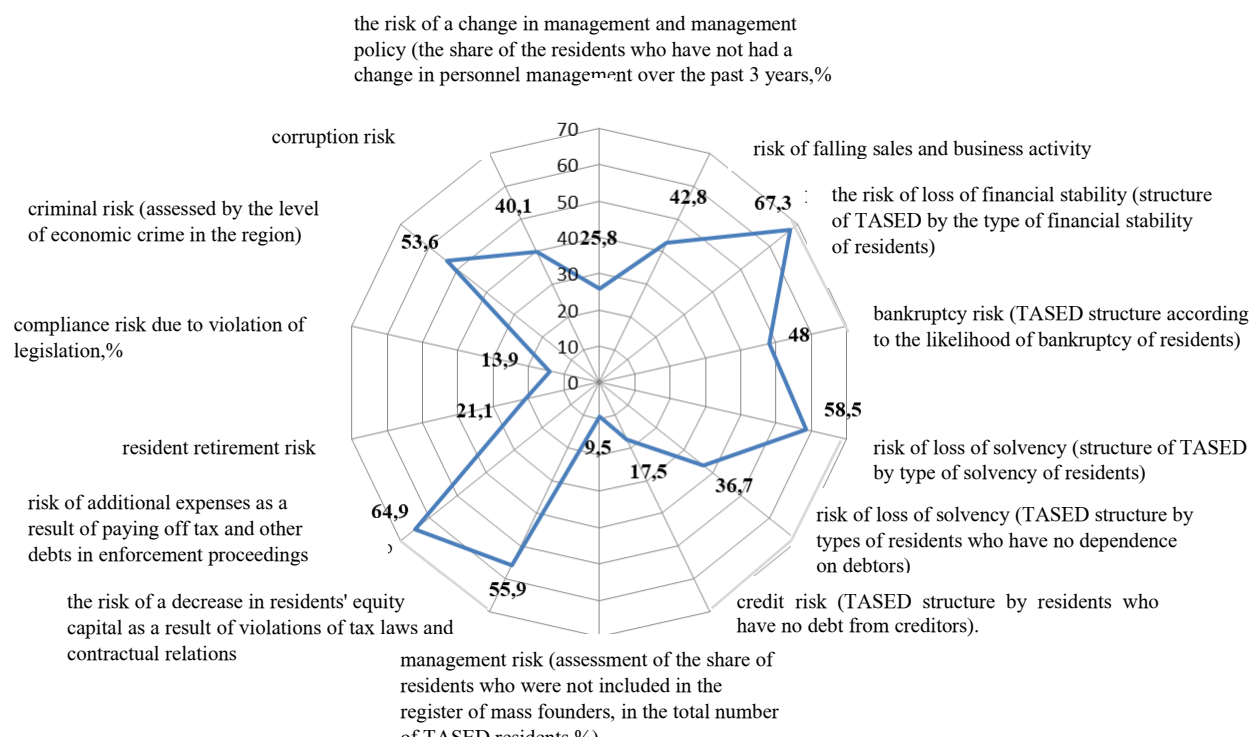

Fig. 1. Comprehensive scoring of compliance risks in the priority development territories of the Russian Far East

The consequences of compliance risks are assessed in the form of accrued fines and penalties for violation of the law, which lead to a decrease in financial stability, as well as loss-making, which becomes a signal of the pre-crisis state of the resident. The reasons for the emergence of compliance risks in priority development areas can be unjustified tax optimization, misuse of funds as a result of corruption crimes, inefficiency and frequent change of management personnel, inefficiency of the regulatory environment, incl. tax, budget and land legislation. The risk of non-compliance with the legislation leads to a delay in the implementation of projects and causes restrictions on attracting new residents to the territory. A significant influence on the change in the value of the compliance risks is exerted by the likelihood of the inspections by the regulatory and supervisory authorities, audit firms, the amount of the fine for non-compliance with the law [11]. E.Asenov notes that the main reasons for the compliance risks fall into two groups of factors:

- internal (non-compliance with the requirements, inconsistency of internal documents with legislation, inability to promptly make changes, ineffective work of lawyers, violation of contractual obligations, outdated information protection system in the context of new technologies and financial innovations);

- external factors (imperfection of the country's legal system, imperfection of methods of state regulation and supervision; violation of contracts by the counterparties, finding the subsidiaries, partners, clients in jurisdictions of other countries) [5].

Reputational risk affects business reputation and has the consequences in the form of civil liability to the buyers, suppliers and investors. The factors of the reputational risk manifestation are the conflicts of interest of residents with the subjects of the external compliance environment (counterparties, customers, partners, competitors) and loss of sales markets, decrease in profitability and disruption of business relations.

The results of the assessment performed indicate that the priority development territories are subject to the risks of loss of the financial stability and solvency, and the onset of bankruptcy. Loss of financial stability may occur in 11 territories ("Bolshoi Kamen", "Komsomolsk", "South Yakutia", "Neftekhimicheskiy", "Gornyy vozdukh", etc.). This fact suggests that despite the inflow of the investments for the implementation of the investment projects, funding is not enough, and only large and medium-sized enterprises 
have accumulated their own resources. At present, the status of TASED residents is granted to companies with technologies of the II-IV technological paradigms. The reasons for the low financial stability of most TASED residents are dependence on borrowed funds and the initial stage of the organization's functioning. There are also the problems with ensuring the solvency of residents. The residents of the Amuro-Khinganskaya TASED have the highest risk of loss of solvency and default on short-term obligations.

The risk of loss of solvency is observed at a high level among the residents of the territories "Bolshoy Kamen", "Komsomolsk", "Yuzhnaya Yakutia", which indicates the delay in repayment of obligations and dependence on the debtors. The residents of the Primorsky and Khabarovsk Territories have stable indicators of solvency, but there is an increase in the amount of the accounts receivable, and, as a result, the accounts payable. High dependence on creditors is noted among small residents of the Bolshoy Kamen territories (LLC Stroyservice-DV), micro-residents of the TASED Neftekhimichesky, small residents of the Khabarovsk territories (LLC DVTG TEO, LLC Complex Logistic Systems). The reasons for high compliance risks are violations of contractual relations both on the part of residents and on the part of their counterparties. Despite tax breaks and preferences, a number of residents have a high tax burden ("Bolshoy Kamen", "Neftekhimicheskiy", "Nikolaevsk", "Priamurskaya", "Amuro-Khinganskaya")

All TASED residents are exposed to the risk of additional costs due to the repayment of costs in relation to legal obligations, enforcement proceedings and tax payments. On the one hand, such facts can lead to the unreliability of the resident as a counterparty, and on the other hand, reduce the image and attractiveness of products, the enterprise as a whole. There is a high probability of unproductive expenses, which can lead to a reduction in own funds.

\section{Conclusion}

It is necessary to take measures to combat the causes and anticipate the consequences of compliance risks, which can be expressed in a decrease in the quality and timeliness of the implementation of projects that are important for ensuring the well-being of the population of the territory and the development of industrial infrastructure. Insufficient efficiency of residents of the territories and failure to meet planned targets can cause uneconomical and ineffective spending of budgetary resources, foreign investments, as well as lead to a deterioration in the image of the Russian Far East and become an obstacle to the implementation of the sustainable development strategy. A measure to prevent the threats to the sustainable development is a monitoring and compliance control system. It is required to eliminate the gaps in federal and regional legislation, introduce a mandatory and effective system of internal control for residents of priority development territories, standardize the procedure for conducting transactions and remove the administrative barriers. It is necessary to ensure the economic, political and social stability, since these factors act as catalysts for corruption risks [12], [13]. The internal compliance control system should ensure a trusting relationship between the business and the state, motivate personnel to follow ethical principles in carrying out operations and fulfilling contractual obligations, make the regulatory framework accessible and understandable for the employees, and provide an information base for inspections by the regulatory authorities. 


\section{References}

1. M. Venkatesan, The Role of Economics: Creating the Sustainable Rational Agent. Int. Adv. Econ. Res., 22 (2016)

2. E.L. Motrich, Problems of forecasting, 5 (2015)

3. Basel committee on banking supervision. Compliance and the compliance function in banks, http://www.bis.org/

4. C. Donald, Langevoort, Behavioral Ethics, Behavioral Compliance, in Research Handbook on Corporate Crime and Financial Misdealing (Jennifer Arlen, ed., Edward Elgar Publishing forthcoming) (2015)

5. E. Asenov, Characteristics of Compliance Risk in Banking, Economic Alternatives, 4 (2015)

6. P. Benedek, Acta Polytechnica Hungarica, 9 (2012)

7. V.Kh. Valiev, Modern problems of science and education, 2 (2015)

8. S.V. Pankova, V.A. Yakimova, Smart Innovation, Systems and Technologies, 172 (2020)

9. S. Esayas, T. MahlerModelling Compliance Risk: A Structured Approach, Artificial Intelligence and Law, 23 (3) (2015)

10. M. Box, K. Gratzer, X. Lin, Small Bus. Econ., 54 (2020)

11. J. Alm, A. Enami, M. McKee, Atl. Econ J., 48 (2020)

12. R. Damania, P.G. Fredriksson, M. Mani, Public Choice 121 (2004)

13. A. Samuel, A. Lowen, Bribery and inspection technology. Econ. Gov., 11 (2010) 